\title{
OBRAZ JAKO AKTOR SPOŁECZNY W SIECI. TREŚCI PRZEKAZYWANE W OBRĘBIE MIKROBLOGÓW NA PRZYKŁADZIE SERWISU SOUP.IO
}

\begin{abstract}
Szubstarska Magdalena, Obraz jako aktor społeczny w sieci. Trési przekazywane w obrębie mikroblogów na przykładzie serwisu soup.io [Images: Actors in the Network] edited by M. Krajewski „Człowiek i Społeczeństwo", vol. XXXIII, Poznań 2012, pp. 79-98. Adam Mickiewicz University Press. ISBN 978-83-232-2484-6. ISSN 0239-3271.
\end{abstract}

\begin{abstract}
Images: Actors in the Network examines the properties of an image floating around the Internet: the ability of connecting people without usage of words, bonding them because of the mutual feelings they have about the reality outside. Images that are reposted between the users of digital forms such as tumblelogs or microblogs (the article uses soup.io for the case study) cover the needs, fears and aspirations of not only ordinary web-users, but also the users of the contemporary culture and economic system. An image is no longer a passive, visual piece - it acts by joining, addressing and portraying the desires, thoughts of the users. This phenomenon can be connected with Bruno Latour's Actor-Network Theory, and with the ideas of W.J.T. Mitchell about the active images. The example of soup.io shows how easy it is to bond people through sharing particular images, but also how certain tools of popular culture can be used to create something new. Although it seems as soup.io users are not interested in connecting with anyone but themselves, their microblog is the message to the outside, it is their collage portrait that makes them visible to the others. Image is then not only the tool of connection, but also the tool of representation. What is important, most of the images that can be found on soup.io are anonymous - which means that they no longer belong to a certain person, but become independent and free to act.
\end{abstract}

Magdalena Szubstarska, Międzykierunkowe Indywidualne Studia Humanistyczne, Uniwersytet im. Adama Mickiewicza, ul. Wieniawskiego 1, 60-712 Poznań, Poland.

\section{WSTĘP}

Żyjemy niewątpliwie w społeczeństwie sieciowym. Określenie to w czasach obecnych nabiera podstępnego podwójnego znaczenia: chodzi nie tylko o powszechność zastosowania i dostępu do sieci jako medium internetu, ale także, a może przede wszystkim o funkcjonowanie nie w obrębie silnie spetryfikowanych struktur, a właśnie w sieci powiązań i splotów. Fenomen różnego rodzaju serwisów społecznościowych, popularność blogów i powszechność dzielenia się treściami za ich pośrednictwem w pewien sposób 


\section{Soup is the only place where I don't pretend I'm okay.}

Reposted from $=$ jadex via 7 maliwa

łączy dwa wspomniane wyżej aspekty sieciowości życia społecznego. Ukazują one nie tylko techniczny wymiar powiązań, ale także niezwykłą dynamikę i płynność rzeczywistości, w której funkcjonujemy. Jednostki wchodzą w "sytuacje sieciowe” - szybko mogą stać się częścią sieci, z łatwością adaptują się do niej, mają również poczucie, że w podobny sposób mogą ją opuścić. Jest to dosyć złudne, ponieważ społeczności ${ }^{1}$ internetowe przestają być wirtualne, mają istotny wpływ na ich życie, podobny do relacji, które są zawiązywane poza komputerem.

Internet, a raczej jego aspekty więziotwórcze, zapewnia również specyficzny wachlarz środków przekazu i wyrazu mający służyć rozbudowywaniu tożsamości jednostki. Dawniej fenomenem i nowym zjawiskiem były anonimowe czaty, na których ludzie mogli wcielać się w dowolną postać i z podobnymi sobie, często nieistniejącymi postaciami nawiązywać relacje. Dziś sposobów tych jest wiele więcej, treść rozmowy nie tylko nie jest podstawą budowania relacji czy tożsamości w internecie, ale często $\mathrm{w}$ ogóle nie występuje, staje się niepotrzebna. Jednostki budują spójny obraz siebie, pomijając ten aspekt komunikacji. Mikroblogging, specyficzna forma blogowania kładąca nacisk na łatwość i szybkość dzielenia i przekazywania treści pomiędzy jednostkami funkcjonującymi w internecie może być odzwierciedleniem nie tylko wspomnianej dynamiki i płynności naszego funkcjonowania $\mathrm{w}$ społeczeństwie sieciowym, ale także właśnie przykładem tej zmiany sposobu komunikacji. Tzw. tumblelogi², których przykładem jest właśnie analizowany przeze mnie jako przykład serwis soup.io, nie tylko umożliwiają proste dzielenie się treścią (contentem), ale w przeciwieństwie do mikroblogów nie muszą precyzować grupy odbiorców i funkcjonować w sieci jako odrębny byt ${ }^{3}$. Inna niż w np. tradycyjnych blo-

${ }^{1}$ Używam pojęcia „społeczności” w najszerszym (jak dla mnie) tego słowa znaczeniu wszelkich form interakcji pomiędzy użytkownikami wyposażonych w sens odczytywany za pomocą wspólnej matrycy kulturowej i celowej.

2Jason Kottke określa tumbelogi jako "szybkie strumienie świadomości” (por. http:/ / www.kottke.org/05/10/tumblelogs, data dostępu: 21.09.2011).

${ }^{3}$ http:/ / kosciak.blox.pl/2010/06/Soupio-czy-Tumblrcom-oto-jest-pytanie.html, data dostępu: 20.04.2011. 
gach jest w nich także relacja pomiędzy obiorcą a nadawcą treści - content umieszczany na mikroblogach lub tumblelogach rzadko jest własnością czy twórczością osoby, która go zamieszcza. Twórca pierwotny jest w przeważającej większości przypadków bezimienny, nie podpisany. Właściciel bloga jest jednocześnie odbiorcą pierwszego rzędu i nadawcą "drugiego rzędu"4, który wpływa na dalsze losy contentu stworzonego przez kogoś innego.

Zauważalny minimalizm i prostota użytkowania soup.io sprawiają, że tym, co określa ich przynależność do jednostki i przejawiającą się $\mathrm{w}$ ten sposób odrębność jest ich treść - jej układ, kolejność, rodzaj, a nie struktura czy wygląd samego bloga. Odgrywają one ogromną rolę o tyle, że są charakterystyczne dla tego właśnie serwisu, ułatwiając poruszanie się po nim i łącząc ze sobą użytkowników. Soup.io jest platformą umożliwiającą umieszczanie lub repostowanie, czyli kopiowanie i przekazywanie dalej wybranych zawartości znalezionych w serwisie. Zawartościami tymi mogą być krótkie filmy, cytaty, animacje oraz obrazy. Ta ostatnia kategoria może wzbudzać zainteresowanie ze względu na zauważalne podobieństwo treści, które można wychwycić "wędrując” od jednego bloga do drugiego. Sprawia ono wrażenie wytwarzania podobnego typu wrażliwości estetycznej oraz ładunku emocjonalnego pomiędzy przekazującymi sobie te treści użytkownikami. Mimo tego, trudno byłoby określić ich jako „społeczność", ponieważ soup.io do minimum ogranicza interakcje pomiędzy blogerami, inne niż przeblogowywanie zawartości - nie istnieje możliwość dodawania rozbudowanych komentarzy ${ }^{5}$, skontaktowania się z wybranym użytkownikiem, można jedynie dodawać ich do listy obserwowanych, by śledzić uaktualnienia ich blogów.

Te właśnie cechy wskazują, czym chciałabym się zająć w mojej pracy: wytwarzanie nieurefleksyjnionej więzi (powiązania) za pomocą procesu przekazywania treści, a nie bezpośredniej, rozumianej w sposób podręcznikowy interakcji. Więź ta jest wytwarzana za jej pomocą, jednak służy nie tyle komunikacji, co budowaniu obrazu samego siebie, uobecnieniu i wizualnemu zaprezentowaniu się. Głównym celem jest tu budowa fasady, manipulacja wrażeniami pozbawiona jednak finału w postaci nawiązania kontaktu. Mikroblog nie jest miejscem nawiązywania znajomości, jest jedynie komunikatem, informacją na temat jego właściciela. Przejawem takiego sposobu wykorzystania potencjału więziotwórczego sieciowości społecznej są właśnie obrazy, ponieważ są najbardziej spójnym sposobem wizualizacji

\footnotetext{
${ }^{4}$ Odwołanie do określeń z języka ekologii jest nieprzypadkowe i może być przyczynkiem do szerszych analiz.

${ }^{5}$ Jedynym sposobem jest opcja »react« dotycząca konkretnego wpisu, nie jest jednak ona często używana.
} 
wspomnianego już wspólnego typu wrażliwości i preferencji estetycznych użytkowników serwisu i mogą być uznane za to, co ich łączy.

Ze względu na opisaną specyfikę przedmiotu analizy, najodpowiedniejszą ramą teoretyczną, umożliwiającą najpełniejsze oddanie tematu, wydaje się być Actor-Network Theory (ANT) opisywana m.in. przez Bruno Latoura (2010), znana również pod polską nazwą teorii aktora-sieci (analizowaną i interpretowaną np. przez Krzysztofa Abriszewskiego [2008]). Umożliwia ona również interdyscyplinarne podejście do interesującej mnie problematyki, ponieważ łączy $\mathrm{w}$ sobie elementy socjologii, filozofii kultury oraz studiów kulturowych. ANT zwraca uwagę i opiera się na założeniu o płynności i dynamice rzeczywistości. Według niej, przymiotnik: społeczny, nie konotuje realnie istniejącej materii, z której zbudowana jest zbiorowość a jedynie moment tworzenia się powiązań pomiędzy działającymi w niej aktorami, specyfiki tworzonej i płynnej więzi (Abriszewski 2008: 251).

B. Latour kładzie też nacisk na przeskakiwanie aktora oraz badacza pomiędzy poziomami tradycyjnie opisywanymi jako mikro i makro. Zjawisko przekształcające świat jest poniekąd ostatnim ogniwem długiego łańcucha reakcji pomiędzy nimi. Aktor działający w takiej sieci również zmienia swoją postać, człowiek jest tylko jednym $\mathrm{z}$ jego rodzajów, wpada w sieć zapośredniczeń oraz mediatorów pomiędzy poszczególnymi elementami. Jest to ważne $\mathrm{w}$ kontekście mojej pracy, ponieważ powiązania pomiędzy analizowanymi tu obrazami mają charakter podobny do opisywanego przez Latoura, można nawet zaryzykować stwierdzenie, że na mikro- lub tumblelogach tworzy się więź pomiędzy obrazami, jedynie zapośredniczana przez jednostki (w innych teoriach wskazywanych za podstawowy budulec życia społecznego). Podział na mikro i makro poziom również zostaje zaburzony $^{6}$ - to, co jest troską jednostki zakładającej i prowadzącej soupa ma swoje połączenie i powiązanie z poziomem systemu, jej funkcjonowania w kulturze (popularnej), stając się wizualizacją wpływu nowoczesności na pojedynczych aktorów.

Od strony technicznej analizy obrazów, jako elementów powiązań pomiędzy ludźmi, posłużyłam się koncepcją W.J.T. Mitchela opisaną m.in. $\mathrm{w}$ What do pictures want?, która niejako wpisuje się w rozważania $\mathrm{z}$ nurtu ANT i pokrewnych. Obraz postrzegany w płaskiej ontologii Latoura, przestaje być jedynie wytworem człowieka służącym jego osobistemu wyrazowi czy tworzeniu szeroko pojętej kultury - „zaczyna” działać, wymuszać działanie, nie jest prostym zapośredniczeniem (przenoszeniem znaczenia bez

${ }^{6}$ Nie jest to może przykład tej wagi i skali, co przywoływany przez Latoura przykład odkrycia szczepionki na wąglika, lecz wbrew pozorom wiele je łączy. (Por. B. Latour, Dajcie mi laboratorium a poruszę świat, w: Teksty drugie 1-2/2009). 
deformacji [Latour 2010: 39]), ze względu na swoje ułożenie pośród innych, na wybranie go przez użytkownika, w pewnym sensie zaczyna istnieć jako mediator, zmieniając obraz jednostki w jej oczach i oczach innych - Mitchell zwraca również uwagę, że działające obrazy nie są „wymysłem” nowoczesności - zachowywały się $\mathrm{w}$ ten sposób na przestrzeni wieków (Mitchell 2005: 7-9). Nie chodzi również tylko o znaczenie obrazów w kontekście semiotycznym, ale ich działanie reprodukowane przez tych, którzy je im nadają, jak pisze Mitchell - zachowują się jakby wierzyli w faktyczne, osobne ich życie, które przez to staje się życiem społecznym (Mitchell 2005: 93). Wydaje mi się, że użytkownicy soup.io, poprzez tworzenie podobnych grup obrazów, które odnoszą do własnej osobowości, tożsamości, relacji ze światem, tak właśnie się zachowują.

Specyfika tematu mojej pracy ukazuje znaczenie pozornie pozaspołecznych czynników, które stają się kluczowe w wytwarzaniu powiązań określanych jako społeczne, tj. dotyczące interakcji symbolicznej pomiędzy jednostkami, stawia także pytanie o ich miejsce w strukturach tego, co nazywamy społeczeństwem, a co okazuje się coraz bardziej być po prostu (lub też aż) siecią tych właśnie powiązań. Warto także podjąć pytanie o status ontologiczny obrazów i powiązanych z nimi relacji - jeśli obserwujemy ich nie do końca uświadamiane działanie, są one zawieszone w rzeczywistości wirtualnej (a więc ich status jako istniejących realnie jest również dyskusyjny) to czy możemy mówić o nich nadal jedynie w kategorii przedmiotów? Przykładem wykorzystania obrazów jako działających aktorów może być wystawa Kłopotliwe obrazy7, w której obserwowano głównie reakcję otoczenia na to, co jest mu przedstawiane. Obraz przestał być bierny, nie służył do zawieszenia wzroku, stawał się impulsem do reakcji.

Zwiększająca obecność obrazów jako nośników znaczeń prowokujących interakcje (np. wzrastająca popularność portali, takich jak kwejk.pl czy poland.pl) sprawia, że warto przyjrzeć się bliżej ich funkcjonowaniu w internecie. $W$ dobie kultury zdominowanej przez media techniczne, w której kompetencje językowe zastępowane są przez kompetencje odbioru serii danych zmysłowych ${ }^{8}$, niezwykle ważną wydaje mi się refleksja nad obecnością obrazów w sieci jako aktorów społecznych. Celem mojej pracy jest zwrócenie uwagi na kilka zaobserwowanych przeze mnie mechanizmów bardziej refleksja nad przedmiotem możliwego pytania niż wyczerpującą odpowiedzią na nie.

${ }^{7}$ Kłopotliwe obrazy, kurator: Marek Krajewski, 6. Biennale Fotografii w Poznaniu, Galeria Miejska Arsenał w Poznaniu, 8.05-7.06.2009.

${ }^{8}$ Wiele ważnych i ciekawych przemyśleń $\mathrm{w}$ dziedzinie filozofii mediów przedstawionych jest w pracach Wojciecha Chyły, np. Chyła (2008). 


\section{METODOLOGIA}

Duża liczba oraz dostępność środków wyrazu oferowanych i dostępnych $\mathrm{w}$ internecie, jest jak już wspomniałam wielkim potencjałem z którego mogą korzystać jednostki w procesach tworzenia i redefiniowania swojej tożsamości. Z drugiej jednak strony, brak fizycznego kontaktu pomiędzy użytkownikami zawieszonymi w takiej sieci powoduje, że intuicja musi być (i często pozostać) głównym narzędziem analizy badawczej. Uzyskanie pewnych, sprawdzonych danych na temat ludzi, którzy pozostają po drugiej stronie jest utrudnione, a w niektórych przypadkach często niemożliwe. Podjęłam jednak próbę zgromadzenia tego rodzaju informacji, poprzez rozesłanie krótkiego kwestionariusza grupie użytkowników soup.io, których blogi analizowałam pod kątem mojej pracy. Wysłałam (w jedynej dostępnej formie kontaktu, opcji react pod konkretnymi obrazami) około 30 linków do pytań zamieszczonych $\mathrm{w}$ formie kwestionariusza GoogleSpreadSheet ${ }^{9}$ i uzyskałam jedynie kilka wymijających odpowiedzi. Być może jest to kwestią sformułowanych pytań, jednak można to również potraktować jako informację zwrotną wskazującą na brak refleksyjności w odniesieniu do tworzenia więzi w obrębie tego portalu. Z drugiej jednak strony, w serwisie można natrafić na obrazy [!], których treść sugeruje lub wręcz informuje postronnego obserwatora (badacza), że użytkownicy widzą pomiędzy sobą podobieństwa lub traktują swój blog jako miejsce osobistego wyrazu.

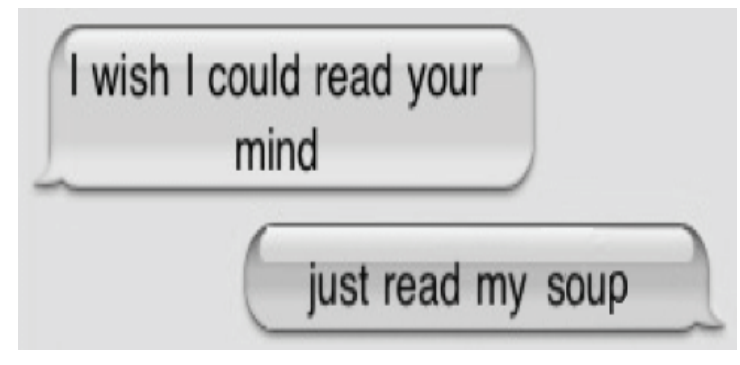

Zdj. 1. http://nikotyna.soup.io

Ta rozbieżność powoduje ryzyko poruszania się w marginesie błędu pomiędzy domysłami a stanem faktycznym, wydaje mi się jednak, że jest on typowy i nieunikniony dla jakichkolwiek badań związanych z rzeczywistością internetową.

\footnotetext{
${ }^{9}$ Narzędzie Google do tworzenia dokumentów, w tym przypadku ankiet i kwestionariuszy.
} 
Obrazy, które możemy znaleźć w serwisie soup.io przedstawiają pewne powtarzalne treści. Do analizy w mojej pracy wykorzystałam głównie pięć różnych blogów, jednak posłużyłam się również tym, co znalazłam na innych, powiązanych z nimi. Dobierałam je pod względem zawartości obrazów; zależało mi również na tym, aby były powiązane ze sobą, np. obraz $\mathrm{z}$ bloga A był zrepostowany przez blog C, z którego trafił na blog D itd.
A. bonnie.soup.io
B. nikotyna.soup.io
C. elesdiego.soup.io
D. kochamsie.soup.io
E. raspberryjam.soup.io

Na użytek analizy, obrazy możemy podzielić na trzy główne kategorie ${ }^{10}$ :

I. tekst na jednolitym tle -

a) białym

b) kolorowym

Przykład I a.

i'm never going to be enough for you.

i'm not pretty, smart, or fascinating.

i'm really fucking sorry.

Zdj. 2. Źródło: blog B

Przykład I b.

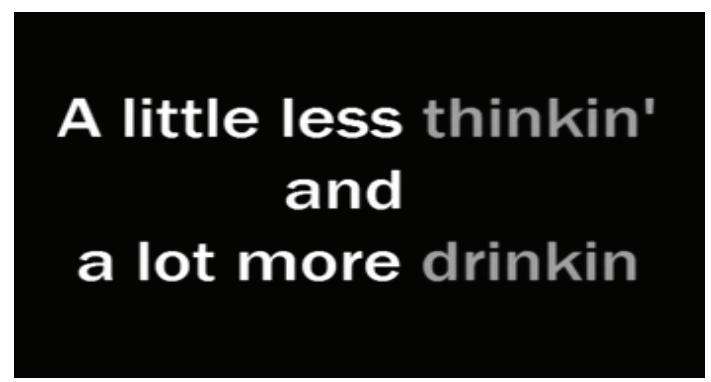

Zdj. 3. Źródło: blog B

${ }^{10}$ Nie są to oczywiście wszystkie rodzaje obrazów, które możemy spotkać na soup.io. Znajdują się tam również proste rysunki, grafiki, obrazy gif, które także włączają się do opisywanej przeze mnie sieci, posiadają jednak inny system znaczeń, przez co mogłyby być przedmiotem odrębnej pracy/analizy. 


\section{II. fotografie/grafiki bez tekstu}

Przykład II

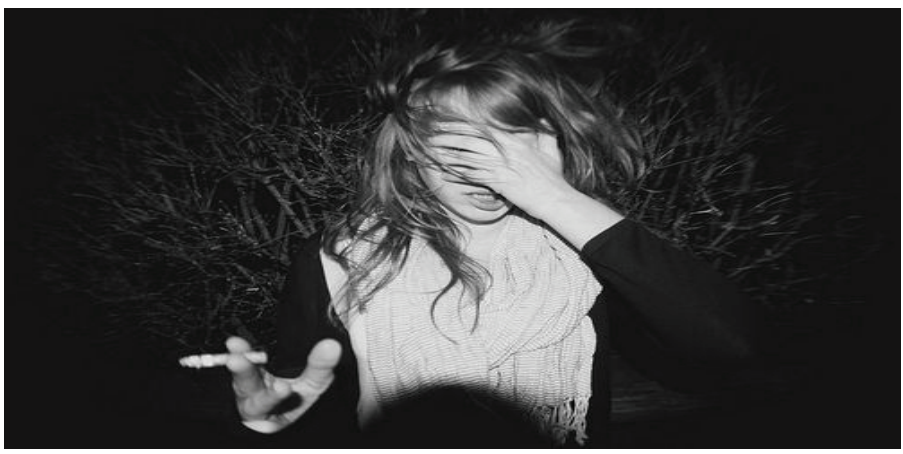

Zdj. 4. Źródło: blog C

III. tekst znajdujący się na fotograficznym [?] tle -

a) wykorzystującym obrazy podobne do kategorii II

b) będący screenem ${ }^{11} \mathrm{z}$ filmu wraz $\mathrm{z}$ napisami (subtitles)

Przykład III a.

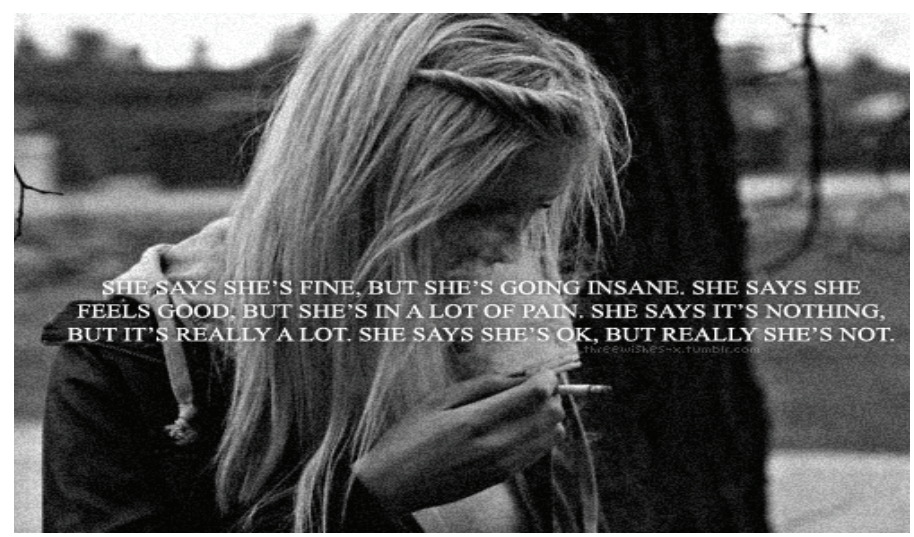

Zdj. 5. Źródło: blog A

${ }^{11}$ Używając tu (i później) określenia „screen”, mam na myśli obraz będący kadrem z fil$\mathrm{mu}$, opatrzony napisami. 
Przykład III b.

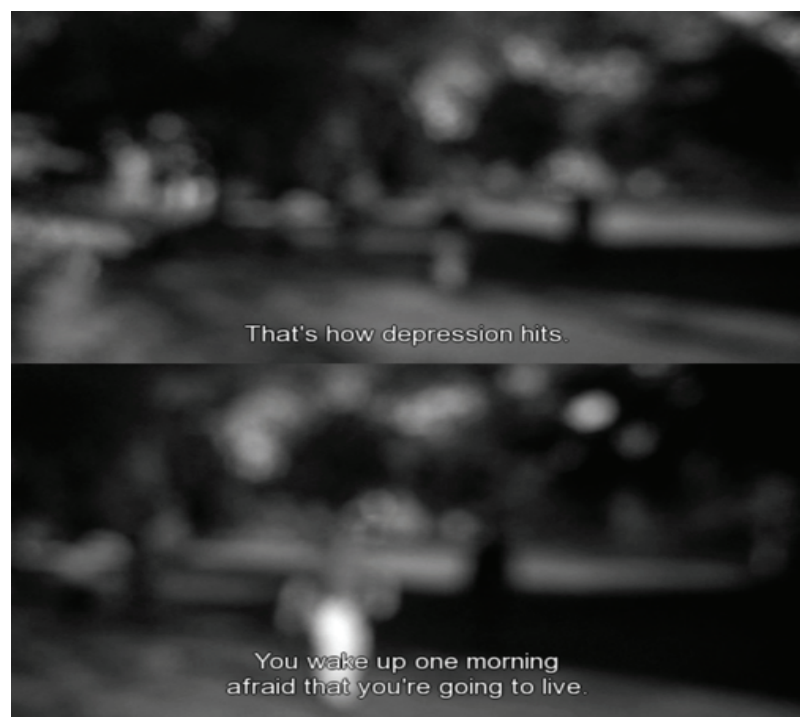

Zdj. 6. Źródło: blog A

Drugim podziałem, dopełniającym kategorie I, II, III jest podział obrazów ze względu na ich treść/ładunek emocjonalny. Jest to czynnik łączący analizowane przeze mnie obrazy, zaraz obok wspólnej estetyki.

\section{OBRAZY MÓWIĄ: „WE FEAR REJECTION, WANT ATTENTION, CRAVE AFFECTION AND DREAM OF PERFECTION"}

Jeden z obrazów, który znalazłam ${ }^{12}$, doskonale oddaje te właściwości i dostarcza w pewnym sensie pojęć operacyjnych do kategoryzacji

12 Chciałabym w tym miejscu naświetlić problem źródeł pochodzenia obrazów zamieszczonych w tej pracy. Pod każdym z nich zaznaczyłam literą blog, z którego „pochodzi”. Wszystkie analizowane przeze mnie blogi mają formę scroll on, czyli nie zawierają podstron, są (nie)skończonym strumieniem contentu, i odnalezienie we wrześniu obrazu znalezionego tam w czerwcu jest praktycznie niemożliwie. Ponadto, obrazy te żyją na wielu blogach jednocześnie, co podkreśla ich mobilność i ulotny charakter. 


\title{
WE FEAR REJECTION, WANT ATTENTION, CRAVE AFFECTION, AND DREAM OF PERFECTION.
}

\author{
Zdj. 7. Źródło: blog E
}

Pierwszą istotną rzeczą, którą możemy odczytać z obrazu, jest użycie zaimka we, czyli my, co może sugerować poczucie wspólnoty (niekoniecznie jej realne istnienie) odczuwania podobnych emocji. Trudno powiedzieć, czy my oznacza w tym przypadku użytkowników serwisu, określone pokolenie młodych ludzi, czy może obie te grupy naraz. Twórca obrazu jest nieznany, niepodpisany, co powoduje, że obraz staje się pozornie anonimowym manifestem nieokreślonej grupy pozbawionym nadawcy czy odbiorcy - mimo tego krąży po serwisie, jest repostowany, a więc w pewnym sensie „podpisywany" przez użytkowników, nie tylko sam w sobie, ale także poprzez realizację postawionych $w$ nim stwierdzeń.

Stwierdzenia te objawiają się w dwóch formach: użytych czasowników, wyróżnionych rzeczowników oraz ich połączenia. Potwierdzane są one poprzez obrazy, które możemy znaleźć w serwisie soup.io

Czasowniki fear, want, crave, dream (boimy się, chcemy, pragniemy, marzymy) są niezwykle silnie nacechowane emocjonalnie. Ich dopełnienia, rzeczowniki rejection, attention, affection, perfection (odrzucenie, uwaga, uczucie, perfekcja) potęgują te emocje i wskazują konkretne wymagania nadawcy/nadawców [?] wobec świata, w którym się poruszają. Każdy ze składników obrazu możemy odnaleźć właśnie na analizowanych przeze mnie blogach.

\section{1. (we) fear rejection}

Strach przed odrzuceniem na soup.io przejawia się na kilka sposobów. Jest to nie tylko obawa przed brakiem akceptacji ale także niechęć do świata, pragnienie ucieczki czy ukrycia swoich prawdziwych uczuć. Fobia ta 
wyrażana jest wprost $\mathrm{w}$ treściach napisów na obrazach $\mathrm{z}$ kategorii I a, takich jak She walks like summer but she looks like rain; a także w filmowych screenach z nadrukowanymi dialogami. Źródeł tego strachu i wynikającego z niego sposobu postrzegania rzeczywistości może być wiele, sama analiza obrazów jest raczej niewystarczającym narzędziem do ich precyzyjnego określenia. Obawa przed odrzuceniem może wiązać się na przykład z multifrenią - lękiem przed podejmowaniem zobowiązań (grożących odrzuceniem) wynikającym z wielości wyborów i możliwości, które istnieją wobec jednostek. Obcowanie nie tylko z ogromną ilością propozycji i wzorów zachowań, ale także przykładów osobistej klęski i ostrzeżeń przed nią, wszechobecnych w kulturze popularnej i odbieranych poprzez zewnętrzną sterowność (brak własnej tożsamości i w rezultacie orientowanie się na innych) może powodować odruch ukrywania się i odgradzania się przed realnym życiem.

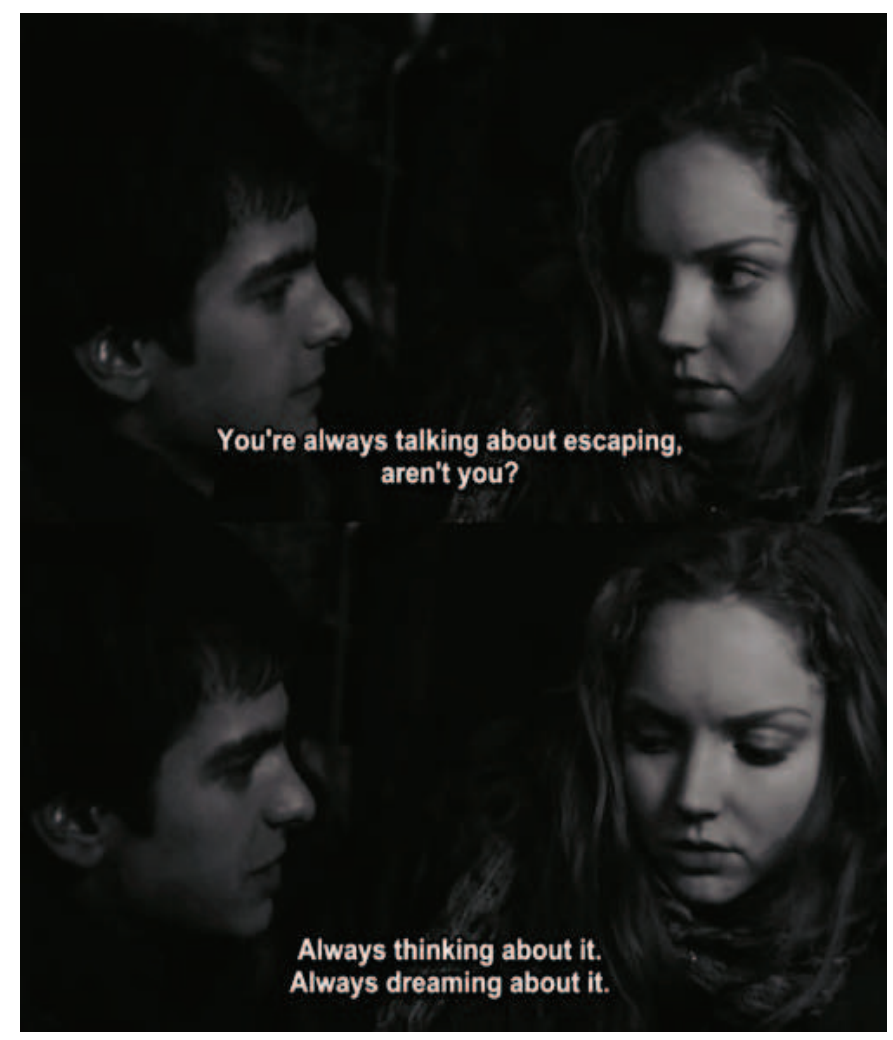

Zdj. 8. Źródło: blog D 


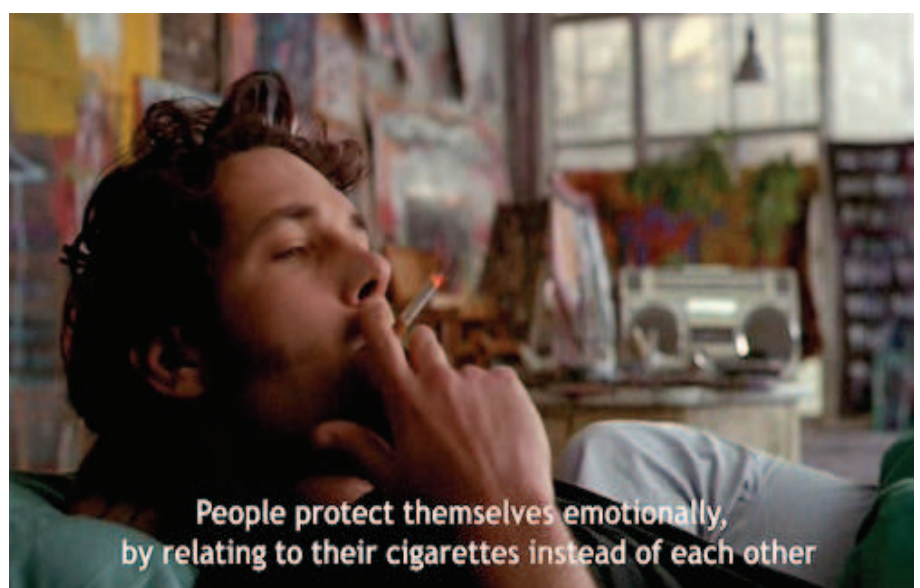

Zdj. 9. Źródło: blog C

\section{"Are you really okay?"}

\section{I am acting like I am okay. Please don't interupt my performance.}

Zdj. 10. Źródło: blog A

\section{2. (we) want attention}

Pragnienie zwrócenia na siebie uwagi to kolejny postulat z obrazumanifestu. Pierwszym krokiem do jego zaspokojenia może być już samo założenie mikrobloga, którego głównym tematem i osią jest sam użytkownik. Chodzi tutaj jednak o atencję świata zewnętrznego, którą można osiągnąć za pomocą różnego rodzaju "artefaktów” - odpowiednich ubrań czy stylizacji, ale także różnego rodzaju zachowań. Przedmioty przedstawiane na obrazach mają często konkretny status w kulturze popularnej, np. alkohol Jack Daniels, marihuana, papierosy czy trampki Converse. Ich zadaniem jest umieszczenie użytkownika w konkretnym kontekście kulturowym, którym jest globalna wioska: są one bowiem wspólne dla grup jednostek, niezależnie od kraju ich pochodzenia czy rodzimej kultury. Przywiązanie do produktu jako narzędzia do określenia samego siebie wywołuje skojarzenia z koncepcjami ekonomii uwagi i potrzeby zwracania tej uwagi na własną osobę. 


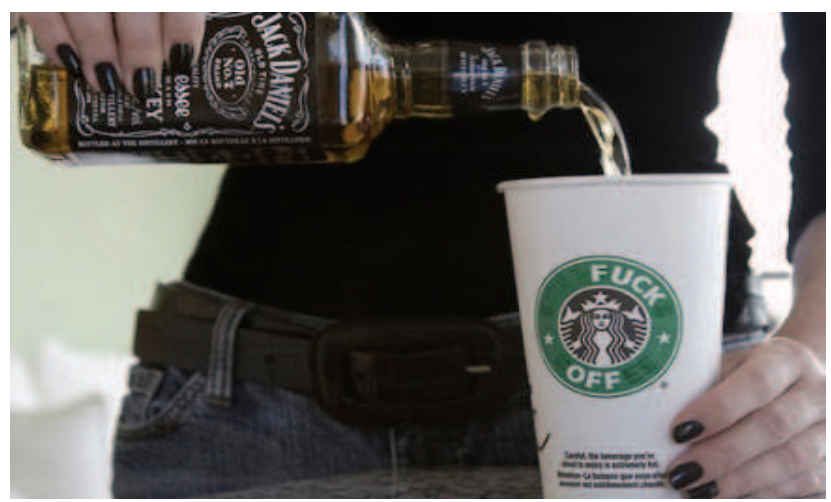

Zdj. 11. Źródło: blog E

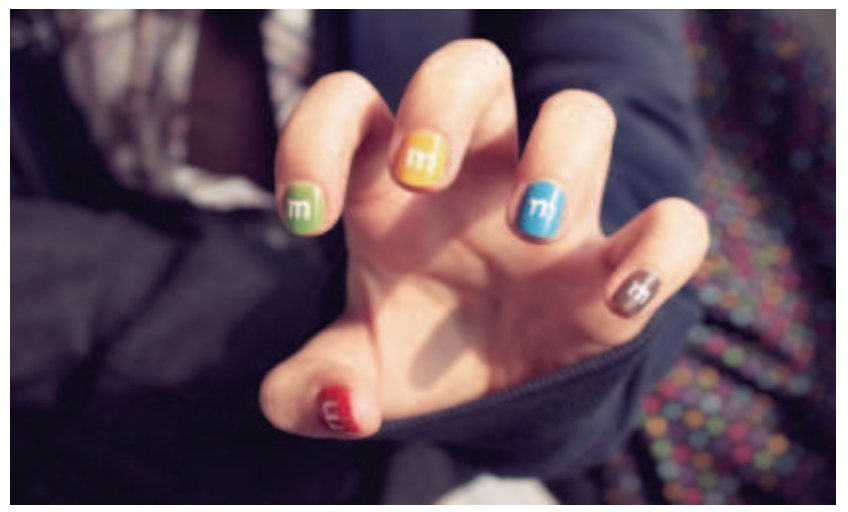

Zdj. 12. Źródło: blog C

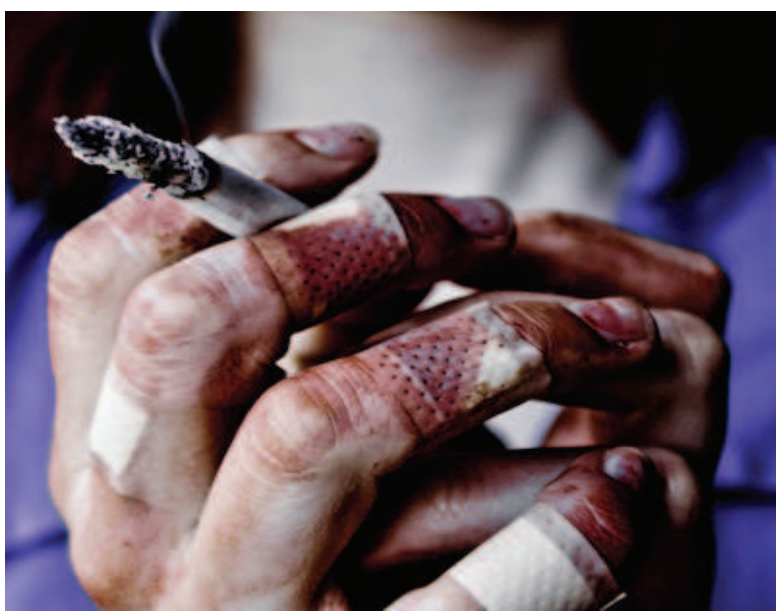

Zdj. 13. Źródło: blog A 


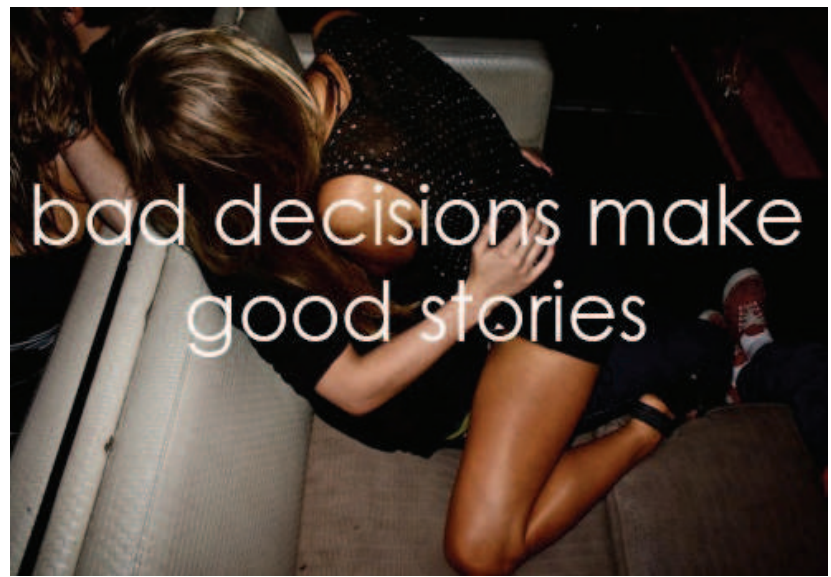

Zdj. 14. Źródło: blog E

\section{3. (we) crave affection}

Uczucie (lub raczej jego brak) jest jednym z głównych tematów obrazów na soup.io. Jest ono przeciwstawiane powierzchownym znajomościom typu one night stand (które nie są negowane: A girl can wait for the right man, but while she waits, can play with the wrong ones). Ważne jest istnienie uczucia nigdy niespełnionego lub wręcz utraconego, z którego wynika strach przed kolejnym odrzuceniem i zranieniem (patrz: we fear rejection). Widać również kojarzenie bliskiej relacji jako ucieczki przed światem, co widoczne jest $\mathrm{w}$ napisach takich jak: I just want someone to come and save me, from life, from fear, from memories, from everything, just take me away Potęgowane poprzez obrazowanie uczucia miłości w kulturze popularnej, $\mathrm{w}$ filmach czy muzyce jest wszechobecne i bardzo uderzające. W pewnym sensie paradoksalnie przewija się tu topos miłości romantycznej: transgresyjnej i opartej na "czystych" relacjach.

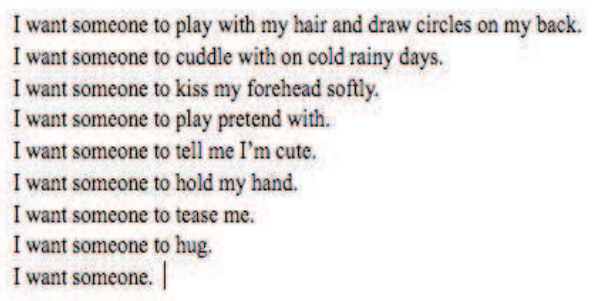

Zdj. 15. Źródło: blog C 


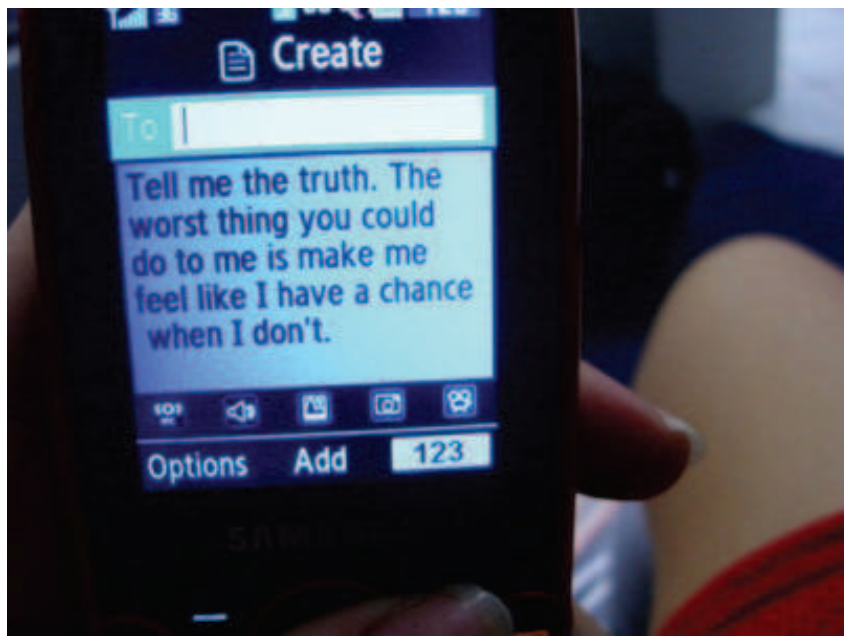

Zdj. 16. Źródło: blog B

Interesującym i powtarzającym się przy tej okazji motywem są obrazowe wariacje na temat piosenki „Love will tear us apart” autorstwa zespołu Joy Division:

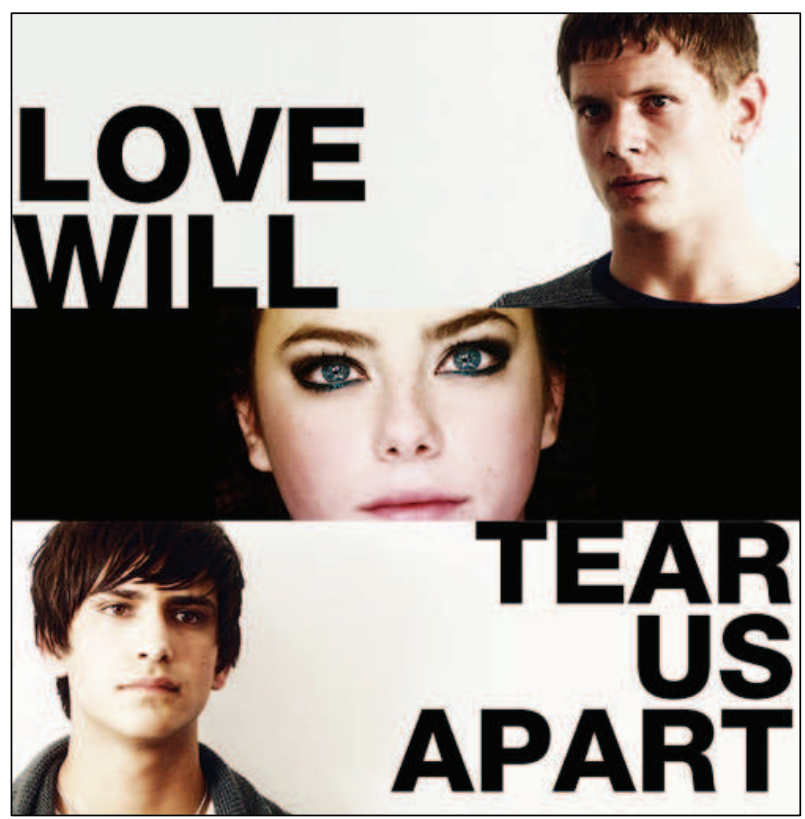

Zdj. 17. Źródło: blog A 


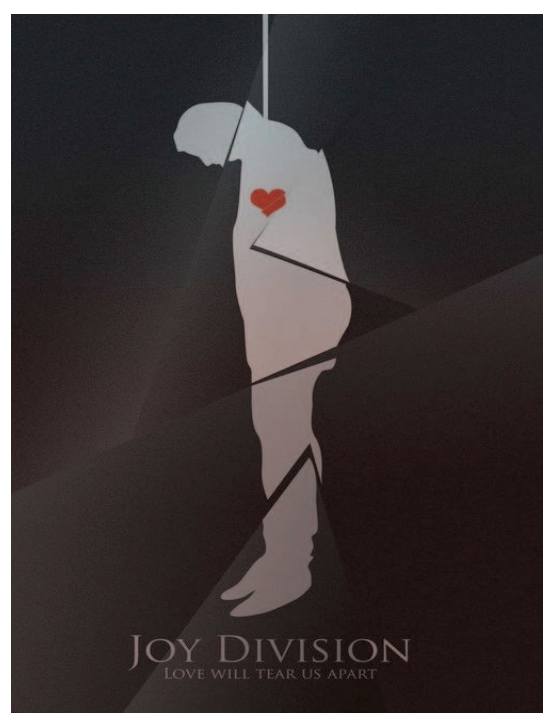

Zdj. 18. Źródło: blog B

\section{4. (we) dream of perfection}

Perfekcja zwizualizowana $\mathrm{w}$ analizowanych przeze mnie obrazach odnosi się głównie do cielesności (wygląd ciała, ubiór, detale dekoracyjne), jednak jest także obecny wątek perfekcji duchowej, przejawiający się w "poukładanym” życiu. Obrazy nie tylko ilustrują cele, ale także je wyznaczają, wskazując sposób ich realizacji. Wskazują na to dokładne przedstawienia fragmentów ciał, np. pomalowanych paznokci czy gotowych zestawów ubrań.

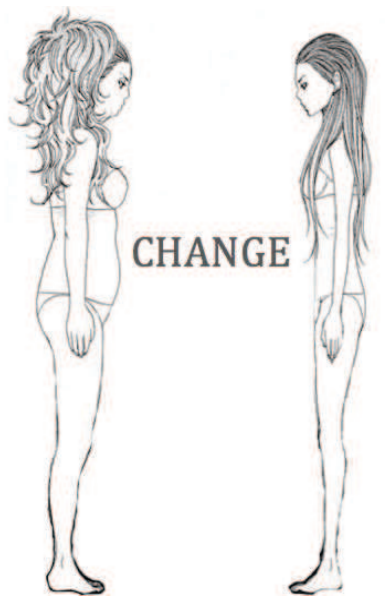

Zdj. 19. Źródło: blog B 


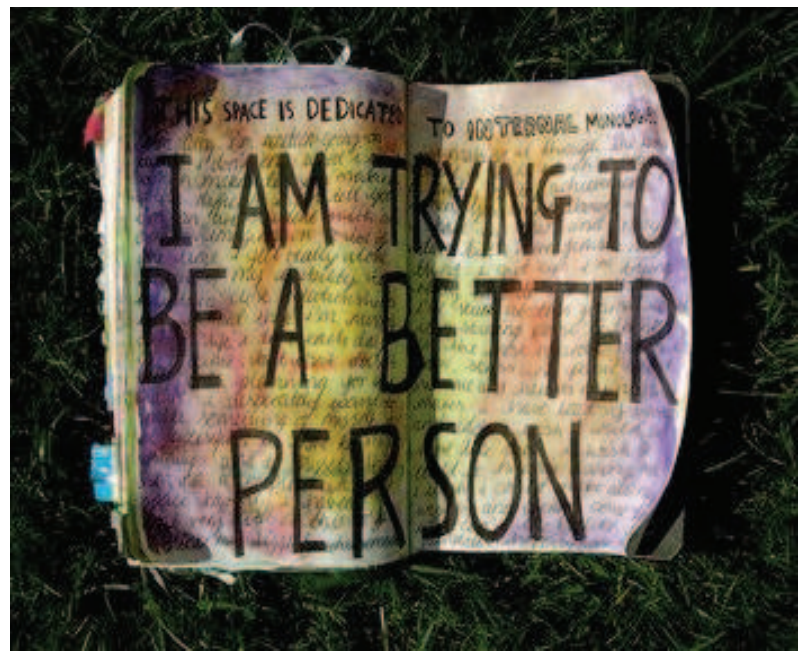

Zdj. 20. Źródło: blog E

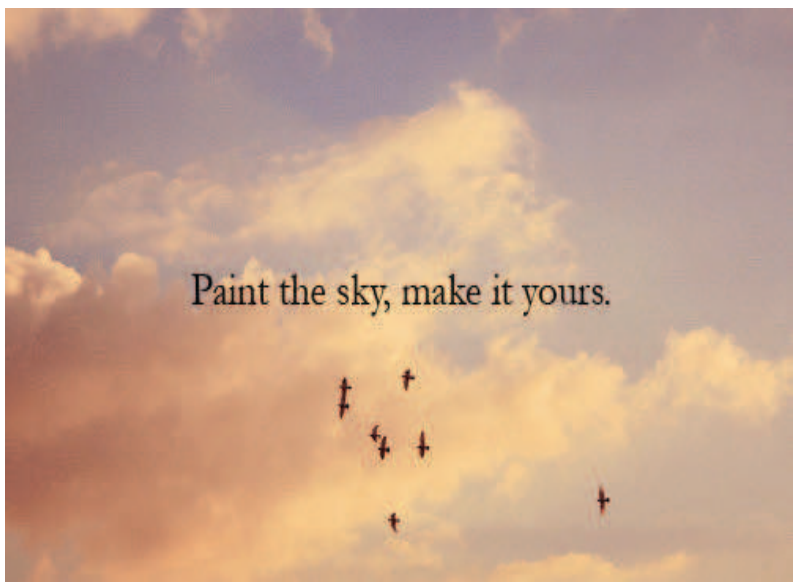

Zdj. 21. Źródło: blog E

\section{POTRZEBY - OBAWY - ASPIRACJE}

Wszystkie opisane przeze mnie kategorie obrazów odnoszą się do trzech głównych pól: potrzeb, obaw oraz aspiracji jednostek mających swoje źródło $\mathrm{w}$ relacjach $\mathrm{z}$ innymi. Ich wizualne przedstawienie jest niewątpliwie powiązane $\mathrm{z}$ funkcjonowaniem użytkowników w określonej kulturze, w tym przypadku wspólnej dla wszystkich kulturze popularnej. Wydaje mi 
się, że można wyodrębnić tu dwa główne aspekty: po pierwsze używanie kultury jako tool-kit (Krajewski 2003; Lamont 1993), a po drugie bycie jej efektem, produktem.

Potrzeby, o których mowa w obrazie-manifeście są z jednej strony uniwersalne, $\mathrm{w}$ pewnym sensie zakorzenione $\mathrm{w}$ naturze ludzkiej i poruszane w rozmaitych kontekstach od wieków. Najciekawszą z nich wydaje mi się być potrzeba atencji, uwagi, skupienia na sobie. Użytkownicy analizowanych przeze mnie blogów to raczej homo hubris (Krajewski 2003: 52). Z jednej strony jest to narcyzm połączony ze stałą niepewnością (mającą odzwierciedlenie $\mathrm{w}$ dążeniu do perfekcji, chodzi tu głównie o ideał szczupłego ciała), mający swoje źródła $\mathrm{w}$ obawie przed odrzuceniem i pominięciem. $\mathrm{Z}$ drugiej - poszukiwanie połączenia $\mathrm{z}$ innymi, potrzeba odnalezienia wspólnoty w takim właśnie postrzeganiu siebie na tle rzeczywistości. Może być to spowodowane nowoczesnym nasyceniem, wielością wspomnianych już środku wyrazu, które stają się dostępne wraz z podłączeniem do sieci.

Mamy tu również do czynienia $\mathrm{z}$ deterytorializacją: brak informacji o miejscu zamieszkania lub pochodzenia nie gra roli podczas analizy obrazów. Przeciwnie, podkreślane jest nieustannie pochodzenie globalne: wspólny język (głównie język angielski), muzyka, filmy, produkty. Wspólne stają się również generowane przez nie potrzeby, pragnienia i aspiracje odzwierciedlane za pomocą obrazów.

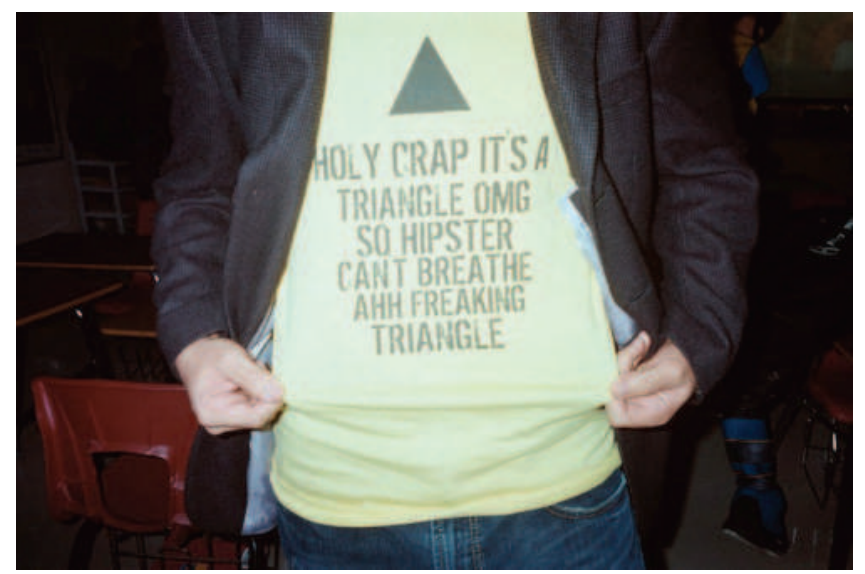

Zdj. 22. Źródło: blog D

Przewodni obraz-manifest wart jest również rozpatrzenia w kontekście bezideologicznej młodzieżowej subkultury hipsterów. Ze względu na jej specyfikę ciężko jest określić, czy użytkownicy omawianych (i nie tylko) przeze mnie blogów w ogóle do niej należą. Cechuje ich z pewnością typo- 
wy dla hipsterów skrajny indywidualizm (specyficzny: zorientowany na innych, rywalizacyjny i wręcz agresywny), niechęć do samego określenia „hipster" (co widoczne jest również na obrazach) z jednoczesnym powielaniem artefaktów i zachowań dla nich charakterystycznych.

Douglas Haddow określił hipsterów jako „kulturę tak bardzo niezaangażowaną, tak bardzo wyłączoną, że nie może z siebie wydać niczego nowego". Z jednej strony fenomen soup.io sugeruje zgodzenie się z tym określeniem - obrazy z powtarzalnymi i istniejącymi wcześniej motywami nie są żadną innowacją $\mathrm{w}$ sensie artystycznym, kulturowym ani społecznym; z drugiej strony - tworząc sieciowy "dziennik emocji” zlepiony z krążących po sieci obrazów, nadając im nową rolę i znaczenie, hipsterzy wyraźnie zaznaczają swoją obecność w społeczeństwie internetowym.

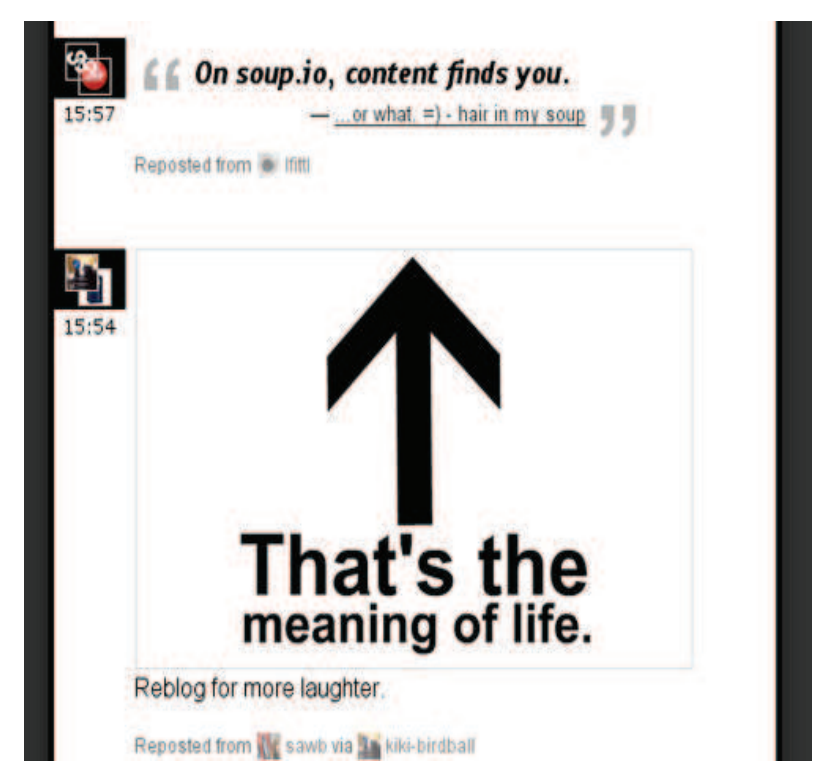

Zdj. 23. Źródło: blog C

Treść mojej pracy nie wyczerpuje oczywiście możliwości interdyscyplinarnych badań i analiz na obszarze obecności obrazów w tumbleloggingu. Warta szerszego omówienia jest $\mathrm{z}$ pewnością rola globalizacji i pojęcia interkulturowości13 jako podłoża specyfiki fenomenu nie tylko soup.io ale również innych serwisów, takich jak na przykład tumblr.com. Ciekawe wydaje się też pytanie czy użytkownicy soup.io posiadają znamiona kultu-

${ }^{13}$ Por. http://www2.uni-jena.de/welsch/ (data dostępu: 10.09.2011) - artykuły Wolfganga Welscha przetłumaczone na j. angielski. 
ry oporu jako pozostającej w opozycji do mainstreamu, czy też raczej są jego sztandarowymi przedstawicielami i piewcami. Treści w obrębie soup.io można rozpatrzeć również w kontekście kultury remiksu jako wizualizację tego, jakie elementy kultury popularnej są najlepiej przyswajalne przez użytkowników tego serwisu oraz sposobu ich wykorzystania, umiejscowienia i interpretacji. Kolejność umieszczania obrazów na blogu nabiera również niezamierzonego znaczenia, gdy przypadkowe zawartości połączą się w jedną: niezwykle wyraźne jest wtedy poniekąd własne życie obrazów w serwisie.

Obrazy, jako działający aktorzy-mediatorzy, w pewnym sensie uspójniają pragnienia, definiują je, uwidaczniają (make visible), umieszczają je w kontekście, pozwalają dzielić się nimi, jednocześnie budując wrażenie współodczuwania. Fragmenty, docelowo nie powiązane ze sobą, stanowią całość. Relacja pomiędzy nadawcą a odbiorcą staje się mglista, niewyraźna, ponieważ prowadzenie bloga na soup.io zdaje się być komunikacją intrapersonalną, dostosowaną indywidualnie, zależną tylko od jednostki i służącą tylko i wyłącznie jej. Jednak opcja przekazywania obrazów między użytkownikami rozszerza, niejako mimowolnie, tę relację na innych, podzielających daną emocję czy uczucie właśnie w postaci obrazu. Możemy wyobrazić sobie taką sytuację jako zgromadzenie ludzi, którzy, nie znając się nawzajem, podają sobie kolejne obrazy połączone ze sobą nicią. Stopniowo sieć ta będzie coraz gęstsza, obrazów i jednostek w niej uczestniczących będzie coraz więcej. Sytuacja ta staje się społecznie nowa, ponieważ trudno zdefiniować jej ramy - teoretycznie są to ramy serwisu soup.io, jednak obrazy dotyczą głównie życia poza nim Niejasne są również początki i końce zachodzących tam interakcji, jeśli już w ogóle uznamy ich istnienie.

\section{BIBLIOGRAFIA}

Abriszewski K. (2008), Poznanie, zbiorowość, polityka. Analiza teorii aktora-sieci Bruno Latoura, Kraków

Castells M. (2008), Społeczeństwo sieci, Warszawa

Chyła W. (2008), Media jako biotechnosystem. Zarys filozofii mediów, Poznań

Krajewski M. (2003), Kultury kultury popularnej, Poznań

Kultura Wspótczesna, nr 2(64) 2010, Warszawa

Lamont M. (1993), Cultivating Differences-Symbolic Boundaries and the Making of Inequality, Chicago-London

Latour B. (2009), Dajcie mi laboratorium a poruszę świat, [w:] Teksty drugie 1-2/2009, Warszawa

Latour B. (2010), Splatając na nowo to, co spoteczne. Wprowadzenie do teorii aktora-sieci, Kraków

Mitchell W.J.T. (2005), What do pictures want? Chicago-London 